\title{
KEBIJAKAN MAJLIS TAFSIR AL-QUR'AN (MTA) DALAM PENETAPAN IDUL ADHA
}

\author{
Imam Qusthalaani \\ Pascasarjana Prodi Ilmu Falak \\ Universitas Islam Negeri Wali Songo \\ Jl. Wali Songo No.3-5 Tambakaji, Ngaliyan Semarang \\ Email: Qustaani@gmail.com
}

\begin{abstract}
Abstrak
Majlis Tafsir al-Qur'an adalah salah satu organisasi Islam yang lahir di Indonesia. Meskipun MTA berkembang di Indonesia, ia mendirikan Idul Adha dengan mengikuti pendirian Idul Adha di Kerajaan Arab Saudi. Ulama sepakat bahwa dalam pelaksanaan Idul Adha di negara muslim harus diterapkan sesuai dengan mathla 'lokal. Pendapat para ulama ini sejalan dengan fatwa MUI tentang keputusan awal Ramadhan, Syawal dan Dzulhijjah nomor 2 tahun 2004. MTA menetapkan Idul Adha dengan menggunakan pengumuman Wukuf Arafah di Saudi karena tidak memiliki metode spesifik dalam membangun awal mula. bulan kamariah. Kebijakan MTA ini juga belum tepat di Indonesia dan perlu ditinjau karena proses penentuan tidak menggunakan pertimbangan astronomi. MTA juga tampaknya tidak konsisten dalam menetapkan awal bulan kamariah karena mengikuti dua metode yang bertentangan, yaitu imkan al-rukyah untuk menetapkan awal ramadhan dan Syawal dan rukyah global untuk menetapkan Idul Adha.
\end{abstract}

Kata Kunci: Majlis Tafsir al-Qur'an, Idul Adha, Pengumuman Wukuf Arafah di Kerajaan Arab Saudi

\begin{abstract}
Majlis Tafsir al-Qur'an is one of Islamic organizations that was born in Indonesia. Although MTA develops in Indonesia, it establish Eid al-Adha by following the establishment of Eid alAdha in Saudi Arabia Kingdom. Ulama agreed that in the implementation of Eid al-Adha in muslim country must be applied accordance with mathla' local. These scholars opinion is in line with the MUI fatwa about the preliminary decision of Ramadhan, Shawwal and Dzulhijjah number 2 of 2004. MTA establishes Eid al-Adha by using the announcement of Wukuf Arafah in Saudi because is has no spesifict method in establishing the beginning of the kamariah month. This MTA policy also not yet proper in Indonesia and needed to be reviewed because the process of determination do not use the consideration of astronomy. MTA also seems inconsistent in establishing the beginning of kamariah month due to following two contradictory methods, namely imkan al-rukyah to establish the beginning of ramadhan and Shawwal and global rukyah to establish Eid al-Adha.
\end{abstract}

Keywords : Majlis Tafsir al-Qur'an, Eid al-Adha, Annaouncement of Wukuf Arafah in Saudi Arabia Kingdom 

a. Pendahuluan

Majlis Tafsir Al-Qur'an selanjutnya disebut dengan MTA merupakan suatu ormas Islam yang mengembangkan dan menyiarkan ajaran Islam dengan cara melakukan penafsiran Al-Qur'an dalam setiap kajiannya. Terkait dengan perayan Idul Adha oleh umat Islam yang sekaligus juga bertepatan dengan pelaksanaan ibadah haji, MTA mempunyai pemahaman atau penafsiran sendiri. Hal tersebut terbukti dengan kebijakan mereka yang menetapkan untuk mengikuti keputusan pemerintah dalam penentuan awal bulan Kamariah yang terdapat ibadah di dalamnya seperti awal Ramadan dan Syawal, namun mengecualikan penentuan awal bulan Zulhijah. Khusus dalam penentuan awal Zulhijah, MTA tidak mengikuti keputusan Pemerintah Indonesia, melainkan dengan tegas mengikuti pengumuman pelaksanaan wukuf dari KerajaanSaudi Arabia. ${ }^{1}$

Apabila kita menelusuri sejarah penetapan Idul AdhaMTA, setidaknya terdapat dua kebijakan yang pernah dikeluarkan. Pada awal berdirinya $^{2}$, lembaga dakwah yang dilegalkan dalam bentuk yayasan ini mengeluarkan kebijakan bahwasanya dalam penetapan awal bulan kamariayah, MTA mengikuti keputusan Pemerintah, kemudian pada tahun 1995 mengeluarkan kebijakan khusus yang berkaitan dengan penetapan puasa Arafah dan Idul Adha dengan mengikuti

\footnotetext{
${ }^{1}$ Lihat Yayasan Majlis Tafsir Al Qur'an Surakarta, Surat Keputusan Nomor 012/Ket/MTA/01/2016, Surakarta, 19 Januari 2016.

${ }^{2}$ Majlis Tafsir Al-Qur'an didirikan oleh AlUstadz Abdullah Thufail Saputra pada 19 September 1972. Lihat Badan Penelitian dan Pengembangan Provinsi Jawa Tengah, Laporan Penelitian tentang Interaksi Sosial Kelompok Aliran Islam Minoritas dalam Masyarakat diberbagai Daerah di Jawa tengah, Semarang: tp, 2008, . 69.
}

pengumuman pelaksanaan wukuf dari Kerajaan Saudi Arabia. ${ }^{3}$

Kebijakan MTA tersebut bertentangan dengan Fatwa MUI tentang Penetapan AwalRamadlan, Syawal dan Zulhijah nomor 2 tahun 2004 yang mengatakan bahwa seluruh umat Islam di Indonesia harus mengikuti keputusan pemerintah dalam penetapan bulan-bulan tersebut, walaupun Indonesia bisa menggunakan hasil rukyat di luar Indonesia yang sama mathla ${ }^{, 4}$ Ulama telah konsensus bahwa dalam pelaksanaan Idul Adha hanya dikenal teori mathla', di mana masing-masing negeri Islam berlaku mathla' setempat. Oleh karena itu penulis akan membahas tentang Kebijakan MTA dalam menetapkan Idul Adha.

\section{b. Profil Majlis Tafsir al-Qur'an}

Majlis Tafsir al-Qur'an atau disingkat MTA adalah lembaga dakwah dalam bentuk yayasan yang didirikan oleh al-Ustadz Abdullah Thufail Saputra pada tanggal 19 September 1972. Ketua umum sekaligus pendiri MTA ini wafat pada tanggal 15 September 1992, setelah 20 tahun ia menumbuhkan dan mengembangkan MTA. Ustadz Abdullah Tufail Saputro, adalah seorang mubaligh yang karena profesinya sebagai pedagang mendapat kesempatan untuk berkeliling hampir ke seluruh Indonesia, kecuali Irian Jaya. Ustadz Abdullah Tufail saputra pada masa

${ }^{3}$ Hasil wawancara dengan pimpinan Pusat Majlis Tafsir al-Quran, Ustadz Ahmad Sukina di kantor pusat MTA pada 19 januari 2016.

${ }^{4}$ Mathla ialah tempat terbitnya benda-benda langit. Dalam bahasa Inggris disebut Rising Place. Sementara itu dalam istilah Falak , mathla' adalah batas daerah berdasarkan jangkauan dilihatnya hilal atau dengan kata lain mathla' adalah btas geografis keberlakuan rukyah. Lihat Susiknan Azhari, Eknsiklopedi Hisab Rukyat, Yogyakarta: Pustaka Pelajar, 2008, cet. II, . 139. 
mudanya belajar agama kepada salah seorang Ulama dari Hadlromi yang menyiarkan agama Islam di daerah pasar kliwon surakarta. ${ }^{5}$

Latar belakang pendirian Majlis Tafsir al-Qur'an adalah didasarkan pada kondisi umat Islam pada akhir dekade 1960-an dan awal dekade 1970-an. Sampai dengan saat itu, umat Islam yang telah berjung sejak zaman Belanda untuk melakukan emansipasi, baik secara politik, ekonomi, maupun kultural justru semakin terpinggirkan. Kondisi umat Islam di Indonesia seperti itu karena kurang memahami al-Qur'an. Sebagaimana ucapan seorang ulama, bahwa umat Islam tidak akan menjadi baik kecuali dengan apa yang telah menjadikan umat Islam baik pada awalnya, yaitu al-Qur'an.

Kepemimpinan

MTA

ditingkat pusat yang sekarang masih eksis merupakan kepemimpinan yang masih terinspirasi dari kepemimpinan sejak berdirinya. Maksudnya, pasca kepemimpinan MTA (Ustadz Abdullah Thufail Saputra) hingga kini pucuk pimpinan masih dipegang oleh Ustadz Ahmad Sukino. ${ }^{6}$ MTA berkembang dengan pesat ke seluruh pelosok tanah air. Pada Silaturrahmi Nasional (Silatnas) pada 27 Desember 2015 yang dilaksanakan di gelora Bung Karno, telah diresmikan 109 perwakilan dan cabang baru, sehingga jumlah pengurus perwakilan dan cabang MTA menjadi 539 yang tersebar dari Aceh sampai Merauke.

Dalam mengembangkan dan menyebarkan dakwahnya, MTA telah menggunakan teknologi informasi.

\footnotetext{
${ }^{5}$ Wawancara dengan Yoyok Mugiatno, sekertaris pusat MTA pada tanggal hari ahad, 20 April 2016 di kantor pusat MTA Surakarta.

${ }^{6}$ Ustadz Sukino merupakan sorang lulusan Institut Agama Islam Muhammadiyah Surakarta yang pernah belajar kepada ustadz Abdullah Tufail selama 18 tahun, sejak tahun (1974-1992). Beliau merupakan seorang pensiunan guru agama.
}

Dalam bidang penerbitan, MTA telah menerbitkan majalah bulanan serta materi pengajian yang disebut brosur. Sesuai dengan tujuan pendirian MTA, yaitu untuk mengajak umat Islam kembali ke alQur'an, kegiatan utama MTA berupa pengajian al-Qur'an yang dapat dibedakan menjadi dua, yaitu pengajian khusus dan pengajian umum. Pengajian khusus adalah pengajian yang siswa-siswanya (juga disebut dengan istilah peserta) terdaftar dan setiap masuk diabsen. Pengajian khusus ini dilakukan seminggu sekali, baik di pusat maupun di perwakilan-perwakilan dan cabang-cabang, dengan guru pengajar yang dikirim dari pusat atau yang disetujui oleh pusat. Pengajian umum adalah pengajian yang dibuka secara umum, siswanya tidak terdaftar dan tidak diabsen. Materi pengajian lebih ditekankan pada halhal yang diperlukan dalam pengamalan agama sehari-hari. Pengajian umum ini baru dapat diselenggarakan oleh MTA pusat yang diselenggarakan satu pekan sekali pada ahad pagi (Pengajian Umum Ahad Pagi), bertempat di gedung MTA jl. Ronggowarsito No. 111 A Surakarta yang diresmikan oleh Presiden DR. H. Susilo Bambang Yudoyono pada tanggal 8 maret 2009.

$$
\text { Dalam bidang teknologi }
$$
informasi MTA telah merambah semua media informasi, antara lain:

1. Media Online: wbsite www.mta.or.id dan e-mail: humas@mta.or.id

2. Radio FM: MTAFM dan Persada FM sejak tahun 2007.

3. Radio Satelit: Telkom-1 freq $3920 \mathrm{MHz}$, S/R 3000 Pol H tahun 2010

4. TV Teresterial: Ch. 52 UHF sejak tahun 2014 
5. TV Online: www.mtatv.net sejak tahun 2010

6. TV Satelite: Telkom-1 freq $3920 \mathrm{MHz}, \mathrm{S} / \mathrm{R} 3000$ Pol H tahun 2010

Dengan adanya media di atas, perkembangan MTA bisa meluas dan berkembang sangat pesat ke seluruh tanah air hingga ke manca negara. ${ }^{7}$

\section{c. Kebijakan Penetapan Idul Adha oleh MTA}

Majlis Tafsir Al-Qur'an, selanjutnya disebut MTA tercatat telah dua kali mengeluarkan kebijakan terkait penetapan Idul Adha. ${ }^{8} \quad$ Kebijakan pertama menetapkan bahwasanya dalam penetapan puasa Arafah dan Idul Adha, MTA mengikuti keputusan Pemerintah Republik Indonesia dalam menetapkan awal bulan Zulhijah. Kebijakan ini juga berlaku dalam penetapan hari raya besar Islam yang lain, seperti awal Ramadan dan Syawal. Kebijakan pertama ini tercatat dikeluarkan pada masa ustadz Abdullah Tufail Saputra selaku pendiri MTA dan berlaku selama 22 tahun (1972-1995). ${ }^{9}$

Selama keberlakuan kebijakan pertama ini, MTA mengikuti keputusan Pemerintah Indonesia secara taklid karena selama itu belum ada warga MTA yang menguasai ilmu falak. Keadaan yang demikian itu mengakibatkan keikutsertaan MTA dalam penetapan awal bulan Kamariahdi Indonesia, khususnya awal bulan Zulhijah dilakukan secara

${ }^{7}$ Pimpinan Pusat MTA, Buku Profil Majlis Tafsir Al-Qur'an,Surakarta: Tp. 2015. Dikeluarkan pada Silaturrahmi Nasional MTA di Gelora Bung Karno pada 27 Desember 2015.

${ }^{8}$ Lihat Yayasan Majlis Tafsir Al Qur'an Surakarta, Surat Keputusan Nomor: 012/Ket/MTA/01/2016, Surakarta, 19 Januari 2016.

${ }^{9}$ kebijakan ini diberlakukan selama 23 tahun. 20 tahun pada masa kepemimpinan ustadz Abdullah Tufail saputra (1972-1992) dan 3 tahun pada masa awal kepemimpinan ustadz Sukina (1992-1995). pasif. Terlebih dengan pandangan mereka bahwasanya penentuan awal bulan Kamariah hukumnya wajib kifayah dan cukup diwakili oleh pemerintah.

Kebijakan MTA dengan bertaklid pada keputusan didasarkan pada status pemerintah Indonesia sebagai ulil amri, di mana pemerintah mempunyai kewajiban dan kewenangan dalam menentukan hari raya di Indonesia. Selain itu, yang semakin meyakinkan MTA dalam mengikuti keputusan pemerintah ialah karena proses perhitungan dan observasi hilal awal bulan Kamariah dilakukan oleh para ahli falak dan didukung dengan peralatan yang bagus.

Dalam menetapkan awal bulan Zulhijah Pemerintah melalui kementrian Agama menyelenggarakan obserasi hilal dengan mengirim para perukyah ke beberapa titik dengan didahului dengan melakukan perhitungan dan kemudian dilaporkan ketika sidang isbat. Sesuai dengan fatwa MUI no. 2 tahun 2004 poin 3, pelaksanaan sidang isbat wajib diselenggarakan dengan berkonsultasi dengan ormas Islam. Sampai saat ini, pimpinan pusat MTA mengaku belum pernah sekalipun mendapat undangan untuk berpartisipasi dalam sidang isbat. Menurut hemat penulis, kebijakan Kementrian Agama yang belum pernah sekalipun mengundang perwakilan MTA dalam pelaksanaan sidang isbat ialah karena tiga hal. Pertama yaitu karena sebagai ormas Islam, MTA belum mempunyai metode dalam penentuan awal bulan Kamariah yang berbeda dengan pemerintah. Kedua, belum ada ahli falak yang bisa mewakili MTA untuk diajak musyawarah dalam sidang isbat dan yang ketiga yaitu karena 
belum jelasnya status MTA sebagai organisasi masyarakat. ${ }^{10}$

Sedangkan kebijakan kedua MTA terkait penetapan puasa Arafah dan Idul Adha, menyatakan bahwasanya dalam penetapan puasa arafah dan Idul Adha, MTA secara tegas mengikuti pengumuman wukuf Arafah Kerajaan arab saudi. Kebijakan kedua ini dikeluarkan dan ditetapkan pada tahun 1995, tepatnya pada tahun ketiga masa kepemimpinan ustadz Sukina, dan masih berlaku sampai sekarang.

Pandangan MTA dengan mengikuti Saudi Arabia dalam menetapkan Idul Adha nampaknya karena didukung oleh kegagalan pemahaman tentang garis tanggal internasional. Dalam salah satu wawancara, Pimpinan pusat MTA menjelaskan "Kegiatan mengikuti keputusan Kerajaan Saudi Arabia hukumnya sah karena selisih waktu antara Indonesia dan Saudi Arabia hanya sekitar 4 jam, sehingga masih terhitung satu hari. Apabila selisih waktu antara antara Indonesia dan Saudi Arabia sampai berbeda hari, maka tidak diperbolehkan mengikuti keputusan kerajaan Saudi Arabia”.

Pendapat pimpinan pusat MTA di atas dapat dipahami bahwasanya terdapat kerancuan pemahaman mengenai garis tanggal. Pengurus MTA nampaknya belum

${ }^{10}$ Anggota MUI Jawa Tengah, Mukhyiddin, menyatakan bahwa status MTA sebagai organisasi Islam masih belum jelas. Beliau menambahkan bahwasanya belum sampai saat ini, belum ada perwakilan dari MTA yang bergabung menjadi anggota MUI Jawa Tengah, begitu juga sama halnya di MUI Pusat, wawancara pada tanggal 20 januari 2016. Ustadz Sukina selaku pimpinan Pusat MTA menjelaskan bahwasanya keanggotaan perwaklan MTA di MUI baru pada tingkat kota surakarta, dengan perwakilan beliau sendiri sebagai Dewan Penasihat MUI Surakarta. Sedangkan pada tingkat yang lain, MTA belum mengikutsertakan perwakilannya. Hanya saja, pada tingkat nasional, beliau menjabat sebagai angota Dewan Pertimbangan MUI Pusat, wawancara dilakukan pada 16 januari 2016 pukul 13:25 WIB. mengetahui perbedaan antara garis tanggal Internasional (Syamsiah) dan garis tangal Kamariah. Dalam konteks penentuan bulan baru dalam penangggalan hijriyah, yang digunakan ialah garis tanggal Kamariah. Sedangkan pemahaman pengurus MTA yaitu menggunakan pedoman garis tanggal Syamsiyah dalam mendukung pertimbangannya dalam penetapan awal bulan Zulhijah, sehingga terdapat kerancuan dan menimbulkan kesalahan dalam penetapan awal bulan Zulhijah.

Untuk memeperjelas penjelasanya, di bawah ini akan digambarkan mengenai garis tanggal Kamariah awal bulan Zulhijah pada tahun 1997. Masuknya Garis tanggal itu menyatakan daerah yang saat terbenam matahari dan bulan bersamaan. Di sebelah barat garis itu pada tanggal 7 April bulan sudah wujud di atas ufuk pada saat maghrib. Sedangkan di sebelah timurnya bulan sudah berada di bawah ufuk pada saat maghrib. Garis tanggal itu melalui pantai barat Australia, pantai barat Sumatra, India, Kazakhstan, dan Rusia bagian barat. Dengan demikian garis tanggal itu memisahkan Arab Saudi dengan Indonesia.

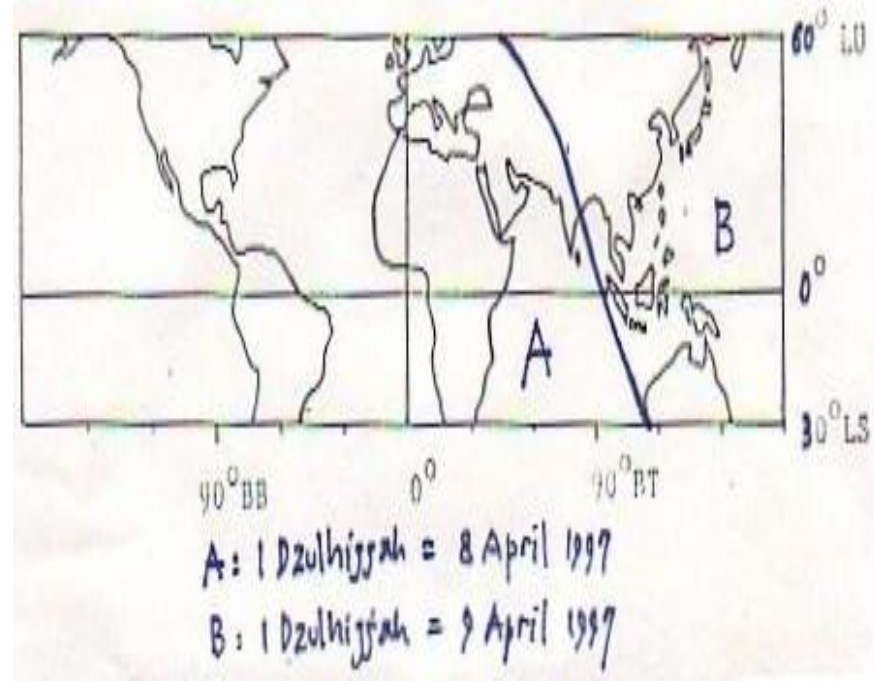


Gambar garis tanggal Kamariahpada 8 dan 9 April $1997^{11}$

Bila kita gambarkan peta berdasarkan garis tanggal Kamariah (lunar date line) kita akan jelas melihat bahwa perbedaan hari Idul Adha antara Indonesia dan Arab Saudi hanya semu belaka. Perbedaan itu hanya disebabkan oleh definisi tanggal syamsiah (solar calendar) yang dipisahkan oleh garis tanggal internasional yang melalui lautan pasifik.

Karena adanya garis tanggal internasional, wilayah di sebelah timur garis itu tanggalnya lebih muda daripada yang di sebelah baratnya. Idul Adha 10 Zulhijah di wilayah Asia Timur jatuh pada 18 April sedangkan di Amerika, Eropa, Afrika, dan Timur Tengah jatuh pada 17 April.

$\begin{aligned} \text { Pengaruh definisi garis } & \\ \text { internasional } & \end{aligned}$ menyebabkan kejadian yang sama dinyatakan dengan tanggal yang berbeda sebenarnya bukan hal yang aneh. Contoh lain yang terkenal adalah catatan sejarah penyerahan Jepang kepada tentara sekutu. Kejadiannya sama, tetapi buku-buku sejarah di Asia, termasuk di Indonesia, menyebutkan tanggal 15 Agustus 1945. Sedangkan di Amerika Serikat menyebutnya penyerahan itu terjadi pada 14 Agustus 1945. Hal ini dianalogikan dengan perbedaan Idul Adha tersebut. ${ }^{12}$

Adapun hadis yang digunakan pertimbangan MTA untuk mengikuti Saudi Arabia dalam menetapkan Idul Adha ialah:

\section{a. Hadis riwayat An Nasa'i}

\section{${ }^{11}$ http://luk.staff.ugm.ac.id/kmi/isnet/Djamal/G} aris-TG97.jpg, diakses pada 12 januari 2016, pukul 09:12 WIB.

12 T. Djamaluddin, Menggagas Fiqih Astronomi, Bandung: Kaki Langit, 2005, Cet. 1, . 13

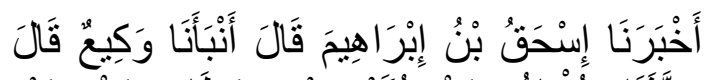

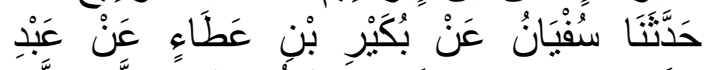

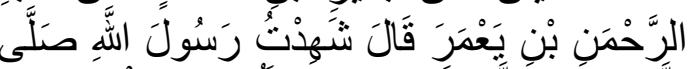

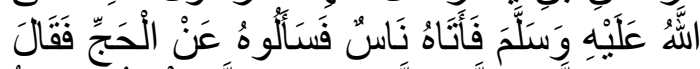

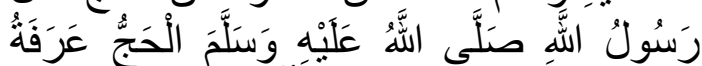

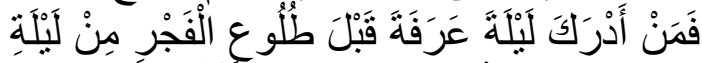

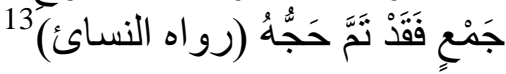

Artinya:Telah mengabarkan kepada kami Ishaq bin Ibrahim, ia berkata; telah memberitakan kepada kami Waki', ia berkata; telah menceritakan kepada kami Sufyan dari Bukair bin 'Atho' dari Abdur Rahman bin Ya'mar, ia berkata; saya menyaksikan Rasulullah shallallahu 'alaihi wasallam didatangi manusia kemudian bertanya kepadanya mengenai haji, lalu Rasulullah shallallahu 'alaihi wasallam bersabda: "Inti Haji adalah wukuf di Arafah, barang siapa yang mendapatkan malam Arafah sebelum terbit fajar dari malam jam' (waktu sore pada hari Arafah maka hajinya telah sempurna". (HR. Nasa'i

b. Hadis riwayat Abu Daud

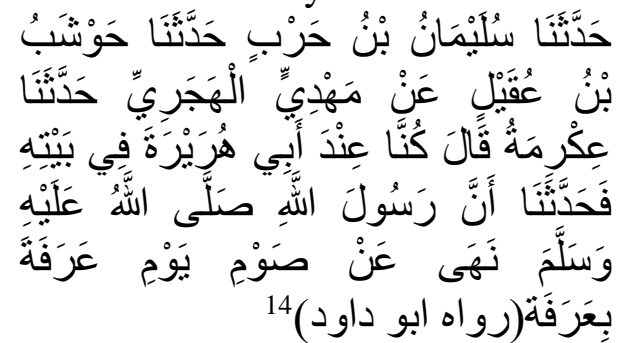

Artinya:Telah menceritakan kepada kami Sulaiman bin Harb, telah menceritakan kepada kami Hausyab bin 'Uqail, dari Mahdi Al Hajari, telah menceritakan kepada kami 'Ikrimah, ia berkata; dahulu kami pernah di sisi Abu Hurairah di rumahnya, kemudian ia bercerita kepada kami bahwa Rasulullah shallallahu 'alaihi wasallam telah melarang berpuasa

${ }^{13}$ Ahmad bin Syu'aib, Sunan al Kubra, , Jilid 2, Beirut: Dar al Kutub Al Ilmiah, 1991, Cet. I, . 424.

${ }^{14}$ Syu'aib, Sunan..., . 420. 
pada hari 'Arafah di 'Arafah. (HR. Abu Daud)

MTA memahami dua hadis di atas dengan menyimpulkan bahwasanya inti dari ibadah haji ialah wukuf di Arafah, sehingga wukuf di Arafah menjadi pembeda antara ibadah umroh dan haji. Dengan mempertimangkan fakta geografis bahwa Arafah itu hanya ada di Saudi Arabia, maka waktu pelaksanaan ibadah yang terdapat pada bulan Zulhijjah, seperti puasa Arafah dan Idul Adha oleh umat Islam yang berada di belahan dunia lain harus disesuaikan dengan pelaksanaan wukuf Arafah di Saudi Arabia.

Terdapat hadis yang bertentangan dengan apa yang disimpulkan oleh MTA mengenai penetapan awal Zulhijjah yang harus diikutkan pada pengumuman Saudi Arabia. Hadis tersebut juga yang dijadian oleh beberapa mazhab yang menganggap penetapan awal bulan harus disesuaikan dengan wilayah hukum suatu negara atau mathla'wilayah masing-masing. Nabi Muhammad bersabda:

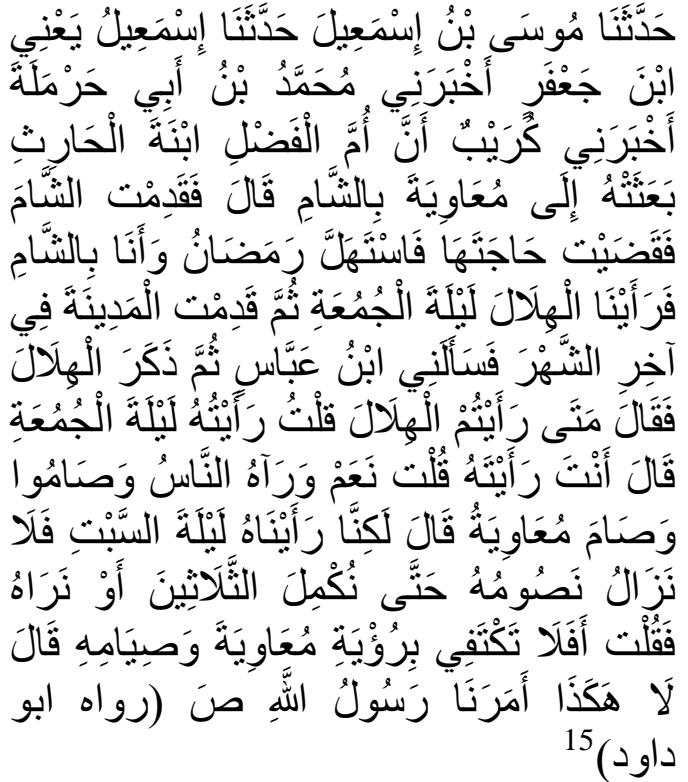

${ }^{15}$ Sulaiman bin As'at, Sunan Abi Daud, Jilid 2, Beirut: Dar al Kutub Al Ilmiah, 1996, Cet. I, . 198
Artinya: Telah menceritakan kepada kami Musa bin Isma'il, telah menceritakan kepada kami Isma'il bin Ja'far, telah mengabarkan kepadaku Muhammad bin Abu Harmalah, telah mengabarkan kepadaku Kuraib, bahwa Ummu Al Fadhl binti Al Harits telah mengutusnya pergi kepada Mu'awiyah di Syam. Ia berkata; aku datang ke Syam, dan menunaikan keperluannya, kemudian telah nampak hilal Ramadlan sementara aku berada di Syam. Kami melihat hilal pada malam Jum'at kemudian aku datang ke Madinah pada akhir bulan. Lalu Ibnu Abbas bertanya kepadaku. -kemudian ia menyebutkan hilal. Kemudian Ibnu Abbas berkata; kapan kalian melihat hilal? Aku katakan; aku melihatnya pada malam Jum'at. Ia berkata; apakah engkau melihatnya? Aku katakan; ya, dan orang-orang melihatnya. Mereka berpuasa dan Mu'awiyah pun berpuasa. Ibnu Abbas berkata; akan tetapi kami melihatnya pada malam sabtu, dan kami masih berpuasa hingga kami menyempurnakan tiga puluh hari atau kami melihat hilal. Aku katakan; tidakkah engkau cukup dengan (ru'yah) yang dilihat Mu'awiyah dan puasanya? Ia berkata; tidak, demikianlah Rasulullah shallallahu 'alaihi wasallam memerintahkan kami.

Menanggapi hadis kuraib, MTA mempunya beberapa alasan yang kemudian dijadikan pertimbangan dalam memahami dan menyimpulkan hadis tentang penentuan awal Zulhijjah. Alasanalsan tersebut antara lain ${ }^{16}$ :

1. Kata 'kalian' pada hadits ru'yah berlaku umum untuk semua orang Islam. Jika ada yang melihat hilal, jujur, terpercaya dan terbukti tanpa memandang

${ }^{16}$ http://mtabrosur.blogspot.co.id/2007_08_01 archive.html\#diakses pada 22 Desember 2015 pada 07:26 WIB. 
perbedaan mathla (tempat munculnya Hilal), maka persaksian itu harus diterima.

2. Umat Islam itu satu, karena itu perlu penyeragaman dalam penentuan hilal bulan Kamariah.

Sebagian kalangan meyakini bahwa pendapat yang mengatakan bahwa setiap negeri memiliki rukyat masing-masing adalah pendapat yang lebih kuat dengan dalil hadits Kuraib yang sudah disebut sebelumnya dan menyatakan bahwa jika pendapat yang mengatakan satu ru'yah untuk semua negeri lebih kuat, maka hadits umum tentang ru'yah itu bertentangan/bentrok dengan hadits Kuraib.

Jika direnungkan lagi, sebenarnya hadits Kuraib tidak bertentangan dengan hadits umum tentang ru'yah. Beberapa alasannya adalah :

1) Pada saat itu negeri-negeri berjauhan dan belum memiliki suatu sistem komunikasi yang canggih dan cepat.

2) Ibnu Abbas bertanya, "Kapan mereka melihat Hilal?" Hal ini menandakan bahwa Ibnu Abbas tidak tahu kapan Mu’awiyah yang merupakan seorang khalifah memulai shaum Ramadlan di Syam, dan Ibnu Abbas baru mengetahui hal itu saat Kuraib mengabarinya. Dengan alasan ini pula menandakan bahwa sekalipun Mu`awiyah mengumumkan berita ru'yah di negerinya, tetapi dia tidak menyebarkannya ke negeri yang lain karena pada saat itu belum adanya suatu sistem komunikasi yang cepat (pada saat itu informasi disampaikan melalui utusan yang waktu tempuhnya dapat berhari-hari sehingga tidak efektif untuk urusan seperti Hilal ini).
3) Aku tiba di Syam, lalu aku menyelesaikan urusan Ummu AlFadhl. Lalu Hilal Ramadlan diumumkan ketika aku masih berada di Syam. Aku melihat hilal pada malam Jum'at. Lalu aku tiba di Madinah pada akhir bulan (Ramadan), lalu Ibnu Abbas menanyakanku -lalu dia menyebut Hilal-. Ibnu Abbas bertanya, "Kapan kalian melihat Hilal?" Kuraib menyampaikan berita Hilal Ramadan di Syam pada Ibnu Abbas di Madinah pada akhir bulan Ramadlan. Kesimpulannya berita Hilal itu sangat telat datang (tapi masih dapat dimaklumi jika melihat kondisi pada saat itu) pada saat shaum sudah berjalan beberapa pekan (hampir sebulan), oleh karena itu Ibnu Abbas menyatakan bahwa mereka (penduduk Madinah) akan meneruskan shaum mereka hingga mereka melihat hilal Syawal atau istikmal. Seandainya berita Hilal Ramadan di Syam bisa tiba tepat waktu di Madinah (dan kondisi seperti ini pada saat itu sangat sulit tercapai), maka belum tentu Ibnu Abbas akan berkata seperti itu.

4) "Tidak, begitulah Rasulullah telah memerintahkan kami",Perkataan Ibnu Abbas ini bisa ditafsirkan dalam beberapa penafsiran, apakah maksudnya adalah :

- Rasulullah memerintahkan rukyathHilal Ramadan berlaku di masing-masing negeri atau

- Rasulullah memerintahkan jika berita hilal Ramadan dari negeri lain sampai dengan telat pada saat negeri itu sedang shaum beberapa pekan, maka penduduk negeri itu sebaiknya melanjutkan shaum mereka. 
Menurut MTA, Pendapat 4b lebih baik daripada 4a sehingga hadis Kuraib ini tidak bentrok dengan hadits hilal secara umum. Seandainya berita Hilal Ramadan di Syam bisa tiba tepat waktu di Madinah (dan kondisi seperti ini pada saat itu sangat sulit tercapai), maka belum tentu Ibnu Abbas akan berkata seperti itu dan Ibnu Abbas sangat mungkin akan mengikuti kesaksian orang-orang yang telah menyatakan melihat Hilal Ramadlan di negeri lain.

5) Rasulullah Shallallahu Alaihi Wasallam saja menerima persaksian orang-orang yang melihat Hilal tanpa menanyakan di mana mereka melihat Hilal. Berikut ini hadits yang diriwayatkan oleh Ibnu Abbas pula :

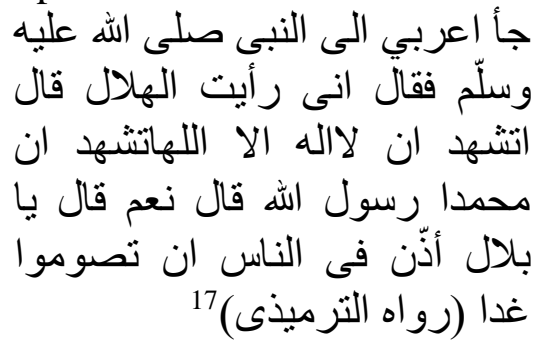

Artinya: Seorang Arab Badui pernah mendatangi Rasulullah Shallallahu 'Alaihi Wasallam dan berkata, "Sesungguhnya aku telah melihat Hilal." Rasulullah bertanya, "Apakah kamu bersaksi bahwa tidak ada Tuhan (yang berhak disembah) kecuali Allah dan bahwasanya Muhammad adalah utusan Allah?" Orang Arab Badui menjawab, "Ya." Rasulullah bersabda, "Wahai Bilal, umumkanlah kepada manusia supaya mereka shaum esok hari!" (HR. At-Tirmidzi)

Menurut hemat penulis, MTA hanya memahami hadis-hadis tentang

${ }^{17}$ Abdurrahman bin Abdurrohim, Tuhfat al Akhwadzi bi Syarkhi Jami' al Tirmidzi, Jilid 3, Beirut: Dar al Kutub al Ilmiah, , 1990, Cet. I, . 372. penetapan awal bulan Zulhijjah secara tekstual, belum disertai dengan ilmu falak. Apabila pemahaman hadis di atas diimbangi dengan pemahaman ilmu falak, mungkin saja MTA tidak mengabaikan begitu saja konsep mathla'. Terlebih, MTA juga menolak pemikiran ulama terdahulu dan memilih langsung memahami dan menghayati Islam dari sumbernya langsung, yaitu Al-Qur'an dan Hadis. Hadis-hadis yang dijadikan dasar dalam penetapan awal bulan Zulhijjah juga tidak menjelaskan atau menganjurkan untuk mengikuti hasil rukyah dari penguasa makkah. Nabi juga tidak pernah memerintahkan untuk mengkhususkan suatu tempat atau wilayah dalam pengamatan hilal. Dengan demikian, kebijakan MTA dengan mengikuti pengumuman penguasa Saudi Arabia tersebut murni berasal dari hasil ijtihadnya, bukan berasal dari anjuran Nabi atau pendapat ulama terdahulu.

Berbeda dengan pandangan MTA, M. Quraish Shihab mempunyai pandangan lain, menurutnya, dalam hal menetapkan tanggal 10 Zulhijah Indonesia tidak boleh mengikuti Saudi Arabia. Selengkapnya ia menyatakan: ${ }^{18}$ "Kita tidak boleh mengikuti Saudi Arabia. Kalau kita mengikutinya kita akan ketinggalan. Bulan Kamariahdimulai dari barat. Ini berarti Saudi lebih dulu. Sedangkan bulan Syamsiah dimulai dari timur. Dalam perhitungan sehari-hari Syamsiyah, Indonesia berarti lebih dulu. Dengan demikian, mathla 'kita berlainan dengan mathla'Saudi Arabia".

Kebijakan kedua MTA juga bertentangan rukyah lokal (mazhab Syafi i) yangberpegang pada mathla, yaitu daerah geografis keberlakuan rukyah untuk penetapan Idul

${ }^{18}$ Susiknan Azhari, Kalender Islam, Kearah Integrasi Muhammadiyah-Nu, Yogyakarta: Museum Astronomi, 2012, . 94. 
Adha. ${ }^{19}$ Menurut madzhab Syafi $i^{20}$, jika terbukti ada rukyat di suatu negeri,rukyat ini hanya berlaku untuk daerah-daerah yang dekat, yaitu yangmasih satu mathla, dengan kriteria satu mathla adalah jarak 24 farsakhataukira-kira $\quad 5544$ $\mathrm{m} / 133,56 \mathrm{~km}$. Sedangkan negerinegeri yang jauh (diatas $133 \mathrm{~km}$ ), tidak terikat dengan rukyat yang terbukti di negeri tersebut.

Pertimbangan paling kuat MTA dalam menentukan puasa Arafah dan Idul Adha dengan mengikuti pengumuman Kerajasaan Saudi Arabia ialah karena wukuf Arafah. Kenyataan tersebut didukung dengan fakta geografis bahwa Arafah, ka'bah dan ibadah haji hanya terdapat dan dilaksanakan di Saudi Arabia. Dengan pertimbangan tersebut, MTA menganggap keberadaan Arafah yang hanya berada di Saudi Arabia mengharuskan umat Islam di negara lain untuk mengikuti pengumuman wukuf Arafah oleh Kerajaan Saudi Arabia.

$\begin{array}{ccc}\text { Gagasan } & \text { MTA tentang } \\ \text { penetapan Idul Adha dengan }\end{array}$ mengunakan patokan keputusan Wukuf Arafah Kerajaan Saudi Arabia akan terkesan sangat positif dan idealis apabila dikaitkan dengan persatuan dan kesatuan Umat Islam di

\footnotetext{
${ }^{19}$ MTA merupakan suatu organisasi Islam yang menyerukan kembali kepada Al-Qur'an dan Hadis. Pengajian keagamaan yang dilakukan langsung dikaji dari sumber pokoknya. Bahkan, pimpinan pusat MTA dengan tegas menyatakan bahwasanya MTA tidak mengikuti salah satu madzhab dalam berakidah maupun berfiqih. Alasan kenapa MTA menolak bermadzhab ialah umat Islam itu harus mengikuti AlQur'an dan Sunnah nabi, bukan mengikuti seorang ulama madzhab. Beliau lantas menambahkan bahwasanya Imam madzhab hanya manusia biasa dan pendapatnya merupakan hasil pemikiranyya, sehingga kita tidak boleh mengikutinya. Hasil wawancara dengan pimpinan MTA pada tanggal 19 Januari 2016.

${ }^{20}$ Wahbah al Zuhaily, Fiqih Shaum, I'tikaf dan Haji (Menurut Kajian Berbagai Mazhab),

Bandung : Pustaka Media Utama. 2006. Cet I. h. 39 .
}

Seluruh dunia. Namun hal tersebut akan menimbulkan beberapa persoalan ketika dibenturkan dengan wilayah astronomis. Hal ini sebagaimana diungkapkan oleh $\mathrm{T}$. Djamaluddin menanggapi perbedaan penetapan Idul Adha antara Pemerintah Indonesia dan Saudi Arabia pada tahun 1417/1997: ${ }^{21}$

Terjadinya perbedaan hari Idul Adha antara Indonesia dan Arab Saudi beralasan secara astronomis. Perhitungan astronomi menyatakan ijtima' awal Zulhijah 1417 terjadi pada 7 April 1997 pukul 11:04 UT atau pukul 14:04 waktu Arab Saudi, pukul 18:04 WIB. Dengan demikian di Arab Saudi ijtima' terjadi sebelum matahari terbenam (ijtima' qabla alghurub) sedangkan di sebagian besar Indonesia saat itu matahari sudah terbenam. Berdasarkan saat ijtima' itu saja dapat difahami bahwa masuknya awal Zulhijah di SaudiArabia lebih dahulu daripada di Indonesia.

Pada tanggal 7 April, di Mekkah matahari terbenam pukul 18:38 sedangkan bulan terbenam lebih lambat lagi, pukul 18:45. Walaupun secara astronomis itu masih di bawah kriteria visibilitas hilal, tetapi itu menunjukkan bahwa bulan sudah wujud di atas ufuk pada saat maghrib. Sehingga 1 Zulhijah di Arab Saudi jatuh pada tanggal 8 April dan Idul Adha jatuh pada 17 April 1997.

Di Indonesia pada tanggal 7 April itu bulan terbenam lebih dahulu daripada matahari. Di Jakarta bulan terbenam pukul 17:54 dan matahari terbenam pukul 17:55. Dan di Bandung bulan terbenam pukul 17:51 dan matahari terbenam pukul 17:52. Di kawasan Indonesia tengah dan timur perbedaan waktu terbenam bulan dan matahari lebih besar lagi.

${ }^{21}$ T. Djamaluddin, Menggagas Fiqih Astronomi, Bandung: Kaki Langit, 2005, Cet. 1, . 1314. 
Secara umum di seluruh Indonesia bulan sudah berada di bawah ufuk pada saat maghrib. Dengan demikian 1 Zulhijah jatuh pada 9 April dan Idul Adha jatuh pada 18 April 1997.

Adapun alasan kenapa harus mengikuti keputusan Saudi Arabia ialah karena kerajaan Saudi Arabia ialah penguasa Makkah yang mempunyai otoritas dalam penentapan waktu pelaksanaan wukuf Arafah dan Idul Adha. Otoritas penetapan wukuf Arafah memang benar-benar berada di tangan Kerajaan Saudi Arabia sebagai pengusa Makkah, namun otoritas terebut tidak dapat diperluas untuk ditaati seluruh umat Islam di dunia. Demikian karena Saudi Arabia merupakan suatu negara yang berbentuk kerajaan, dimana kekuasanya hanya berlaku di wilayah negaranya saja. Berbeda ketika zaman khilafah islamiah, di mana pada waktu itu otoritas Khalifah berlaku bagi seluruh umat Islam, sehingga keputusannya harus ditaati oleh seluruh umat Islam di dunia.

Hilal syar'i yang

dikembangkan oleh Saudi Arabia dan kemudian diikuti hasilnya oleh MTA juga tidak begitu jelas. Sering terjadi kontroversi dengan keputusan rukyatnya. Tampaknya setiap laporan rukyathilallangsung diterima tanpa adanya konfirmasi benar tidaknya hilal yang teramati itu. Mungkin dasarnya hanya keimanan dan kejujuran pengamat hilal tersebut.

Penetapan awal bulan Zulhijah yang kontroversial pernah dikeluarkan oleh Saudi Arabia pada tahun 1999. Menurut Hisab Astronomi, pada 17 maret 1999 di Makkah matahari terbenam pukul 18:31 waktu setempat dan bulan terbenam pukul 18:19. Bagaimana mungkin hilal terlihat pada saat maghrib di Saudi Arabia, padahal bulan telah terbenam. Apalagi ijtima' baru terjadi pada pukul 21:50 waktu setempat (18 maret 1999, 01:50 WIB). Tidak mungkin terjadi hilal sebelum ijtima'. Pasti yang dilaporkan oleh pengamat di Arab tersebut, bukan hilal. Mungkin objek terang yang dikira hilal, mungkin juga bulan sabit akhir bulan yang teramati waktu pagi yang sebenarnya bukan hilal. ${ }^{22}$

Kegiatan MTA dalam mengikuti pengumuman wukuf Arafah dari kerajaan Saudi Arabia boleh dikatakan sebagai bentuk taklid buta. Pengurus MTA hanya mencari berita tentang pengumuman dari Kerajaan Saudi Arabia, tanpa mengetahui metode apa yang digunakan oleh Saudi Arabia dalam menentukan awal bulan di negaranya.

Ustadz Sukina menjelaskan bahwa salah satu faktor yang menyebabkan perubahan kebijakan penetapan Idul Adha dengan mengikuti pengumuman wukuf Arafah Kerajaan Saudi Arabia ialah pada tahun 1995, masyarakat Indonesia dan khususnya pengurus MTA sudah mampu mengkses pengumuman tersebut melalui surat kabar, siaran radio maupun tayangan televisi. Pada saat itu juga umat Islam Indonesia sudah bisa menyaksikan pelaksanaan siaran ibadah haji lewat media elektronik, baik radio maupun televisi.

Sejak awal penerapan kebijakan kedua ini, pengurus MTA belum pernah menjalin hubungan kerjasama secara resmi dengan kerajaan Saudi Arabia. Pengurus MTA hanya menyimak pengumuman wukuf Arafah dari Kerajaan Saudi Arabia kemudian menyebarkan berita tersebut kepada selruh warganya melalui pengurus perwakilan dan cabang di daerah-daerah. Fakta tersebut semakin menunjukan 
bahwasanya MTA hanya bertaklid kepada kepada pengumuman wukuf Arafah Saudi Arabia tanpa berusaha menelusuri asal-usul pengumuman itu dapat dikeluarkan, atau tanpa terlebih dahulu mencari tahu bagaimana tata cara penentuan awal bulan Zulhijah oleh Saudi Arabia. MTA terkesan menelan mentah-mentah apa yang diumumkan Saudi Arabia kemudian mengumumkanya kepada warganya untuk kemudian dijadikan patokan di Indonesia.

Kegiatan taklid terhadap penetapan awal bulan Zulhijah oleh kerajaan Saudi Arabia dengan mengabaikan kesaksian rukyat di daerah lain pada dasarnya bertentangan dengan perintah Nabi dalam menentukan awal bulan. Nabi Muhammad tidak pernah memerintahkan secara khusus untuk melihat hilal di suatu tempat tertentu. Dan apabila MTA tetap menetapkan awal bulan Zulhijah berdasarkan pengumuman dari Saudi Arabia, bisa saja pelaksanaan puasa Arafah dilakukan pada hari yang diharamkan untuk puasa secara hakiki, dan pelaksanaan salat Idul Adha dilakukan tidak pada waktu setempat, maksudnya pelaksanaan salat Idul Adha dilakukan tidak pada waktu setempat (WIB, WITA atau WIT), tapi dilakukan pada waktu Saudi Arabia.

Pandangan MTA yang mengangap bahwasanya penetapan awal bulan Kamariah merupakan fardlu kifayah dan berpandangan bahwa MTA sampai saat ini belum perlu mempelajari ilmu falak nampaknya perlu dikoreksi kembali. Pasalnya, kebijakan kedua MTA dalam menetapkan Idul Adha dengan mengikuti pengumuman Saudi Arabia membuktikan bahwasanya dalil tentang penetapan awal bulan Kamariah tidak dipahami dengan ilmu pengetahun yang bersangkutan.
Oleh karena itu, menurut kaca mata ilmu pengetahuan, kebijakan MTA yang kedua mengenai penetapan Idul Adha belum bisa dibenarkan.

Perubahan kebijakan MTA dalam menetapkan Idul Adha, bisa dipahami sebagai bentuk ketidakkonsistenan MTA.

Ketidakkonsistenan MTA dalam hal ini bisa dilihat dari dua hal, yaitu dari segi bertaklid terhadap suatu metode dan ketaatan terhadap ulil amri.

Dari segi metode yang diikuti, MTA telah menetapkan rukyat hilal sebagai cara penetapan awal bulan Kamariah, namun hanya sebatas teori. Dalam praktiknya MTA jelas mengikuti dua metode dalam menetapkan awal bulan Kamariah. Dalam penetapan awal Ramadan dan Syawal, MTA mengikuti keputusan pemetintah Indonesia. Adapun metode yang dipegangi pemerintah Indonesia adalah metode imkan alrukyah dengan mathla' fi wilayah alhukmi. Sedangkan dalam menetapkan Idul Adha, MTA mengikuti pengumuman hasil rukyah syar'idari Kerajaan Saudi Arabia

Menurut hemat penulis, dengan rukyat hilal yang dipegangi MTA secara teori dan dengan belum adanya kemampuan oleh MTA untuk melakukan praktik rukyat, dan kemudian memutuskan mengikuti pemerintah yang menggunakan metode imkan al-rukyah dengan mathla' fi wilayah al-hukmi, nampaknya keputusan tersebut perlu ditinjau kembali. Kalau MTA berani konsisten dengan rukyat hilalnya, maka seharusnya MTA menetapkan awal bulan Zulhijah dengan selalu mengikuti hasil dari rukyat hilal, baik hasil rukyat hilal yang dilakukan pemerintah, maupun dari ormas lain. Apabila MTA hanya mengikuti keputusan pemerintah, maka ketika terjadi suatu penetapan awal bulan yang tidak berdasarkan hasil rukyat, 
namun berdasarkan kriteria visibilitas hilal imkan al-rukyah karena hilal tidak bisa teramati dan MTA tetap mengikuti Pemerintah, maka akan terjadi inkonsistensi, sebagaimana pernah terjadi pada penetapan awal Ramadan tahun 1422 H. Sedangkan mengikuti hasil rukyah syar'i kerajaan Saudi Arabia juga belum bisa dibenarkan sepenuhnya karena terdapat perbedaan mathla' antara Indonesia dan Saudi Arabia.

Sedangkan dari segi ketaatan terhadap ulil amri, nampaknya terdapat dualisme ketaatan yang dilakukan oleh MTA yang idealnya hanya ditujukan kepada satu ulil amri, yaitu pemerintah Indonesia. Ketundukan MTA terhadap keputusan Saudi Arabia terkait penetapan Idul Adha nampaknya perlu dipertanyakan, mengingat otoritas Kerajaan Saudi Arabia hanya berlaku di wilayah negaranya. Sedangkan MTA merupakan suatu organisasi Islam yang berafiliasi dalam bentuk Yayasan yang lahir, didaftarkan dan berkembang di Indonesia.

Perlu diingat, pandangan MTA dalam penetapan Idul Adha dengan mengikuti Saudi Arabia dapat dibenarkan terbatas pada pelaksanaan ibadah haji. Maksudnya, pelaksanaan Idul Adha dan Ibadah haji yang dilaksanakan di Saudi Arabia tidak boleh ditetapkan berdasarkan penetapan negara lain. Sehingga tidak diperbolehkan melaksanakan wukuf di Arafah berbeda hari dengan wukuf yang diselenggarakan Kerajaan Saudi Arabia karena mendasarkan penetapan awal bulan berdasarkan penetapan negara asalnya. Jadi, apabila terdapat penetapan awal bulan Zulhijah antara pemerintah Indonesia dan Kerajaan Saudi Arabia, pelaksanaan ibadah haji Indonesia tetap harus mengikuti penetapan Kerajaan Saudi Arabia karena pemerintah Saudi merupakan panitia yang mempunyai otoritas dan bertanggung jawab dalam pelaksanaan ibadah haji.

Menurut hemat penulis, benang merah dari dikeluarkannya kebijakan MTA dengan mengikuti keputusan Kerajaan Saudi Arabia dalam penetapan Idul Adha yaitu adanya kemiripan ${ }^{23}$ cara berfiqih yang dianut dan dikembangkan oleh MTA dengan cara berfiqih Wahabi, paham yang dianut secara resmi oleh Kerajaan Saudi Arabia. Kemiripan keduanya terletak pada cara pemahaman mereka terhadap nash yang cenderung tekstual, tanpa adanya usaha penafsiran. Mereka membaca dan menyimpulkan hukum sesuai dengan apa yang ditertulis dalam Al-Qur'an dan Sunnah. Dengan demikian, dapat dikatakan bahwa sebenarnya, mazhab fiqih yang dianut oleh MTA dan Wahabi ialah madzhab Zhahiri, mazhab yang didirikan oleh Daud Al-Zhahiri, yang kemudian dikembangkan dan dipopulerkan oeh Ibnu Hazm.

\section{d. Kesimpulan}

Dari pembahasan di atas ialah secara teoritis, MTA dalam menetapkan Idul Adha memegangi rukyat hilal sebagai metode penetapan awal bulan Kamariah. Namun karena belum adanya ahli falak dan kemampuan untuk melaksanakan rukyat, maka dalam praktiknya, MTA mengikuti keputusan pemerintah dalam menetapkan awal Ramadan dan

${ }^{23}$ Kemiripan lain dari keduanya setidaknya tercermin dalam beberapa hal yang sama-sama selalu dikampanyekan oleh keduanya. Pertama, semangat kembali kepada Al-Qur'an dan Sunnah., semangat puritansisasi dalam Islam, kebencian terhadap mistisme dan sektarianisme, menganggapsemua inovasi dalam islam sebagai perbuatan bid'ah dan kurang menghormati ulama yang berbeda pandangan. 
Syawal, dan pengumuman Saudi Arabia dalam menetapkan awal Zulhijah. Kebijakan di atas menurut hemat penulis mengandung inkonsistensi dalam dua hal, yaitu dari segi metode dan ketaatan kepada ulil amri. Kebijakan MTA dengan mengikuti pemerintah dalam menetapkan Ramadan dan Syawal akan terkesan tidak konsisten apabila tetap mengikuti pemerintah ketika awal bulan ditetapkan berdasarkan kriteria visibilitas hilal imkan al rukyah karena hilal tidak bisa teramati. Kebijakan MTA dengan mengikuti rukyah syar'i Saudi Arabia juga belum bisa diterima secara fiqih maupun astronomi karena bertentangan dengan mathla'. Sedangkan dari segi ketaatan terhadap ulil amri, seharusnya MTA hanya menaati satu ulil amri, yaitu Pemerintah Indonesia.

\section{Daftar Pustaka}

Abdurrohim, Abdurrahman bin, Tuhfat al Akhwadzi bi Syarkhi Jami' al Tirmidzi, Jilid 3, Beirut: Dar al Kutub al Ilmiah, Cet. I, 1990

As'at, Sulaiman bin, Sunan Abi Daud, Jilid 2, Beirut: Dar al Kutub Al Ilmiah, Cet. I, 1996

Azhari, Susiknan, Eknsiklopedi Hisab Rukyat, Yogyakarta: Pustaka Pelajar, cet. II , 2008

Integrasi Muhammadiyah-Nu, Yogyakarta: Museum Astronomi, 2012

Djamaluddin, T., Menggagas Fiqih Astronomi, Bandung: Kaki Langit, Cet. 1, 2005

MTA, Pimpinan Pusat, Buku Profil Majlis Tafsir Al-Qur'an,Surakarta: Tp. 2015

Surakarta,Yayasan Majlis Tafsir Al Qur'an, Surat Keputusan Nomor : 012/Ket/MTA/01/2016, Surakarta, 19 Januari 2016.
Syu'aib, Ahmad bin, Sunan al Kubra, , Jilid 2, Beirut: Dar al Kutub Al Ilmiah, Cet. I , 1991

Tengah ,Badan Penelitian dan Pengembangan Provinsi Jawa, Laporan Penelitian tentang Interaksi Sosial Kelompok Aliran Islam Minoritas dalam Masyarakat diberbagai Daerah di Jawa tengah, Semarang: tp, 2008

al Zuhaily, Wahbah, Fiqih Shaum, I'tikaf dan Haji (Menurut Kajian Berbagai Mazhab), Bandung : Pustaka Media Utama, Cet I, 2006.

Wawancara dengan Yoyok Mugiatno, sekertaris pusat MTA pada tanggal hari ahad, 20 April 2016 di kantor pusat MTA Surakarta.

http://luk.staff.ugm.ac.id//kmi/isnet/Djamal/G aris-TG97.jpg, diakses pada 12 januari 2016, pukul 09:12 WIB.

http://mtabrosur.blogspot.co.id/2007_08_01 archive.html\#diakses pada 22 Desember 2015 pada 07:26 WIB. 